\title{
An Empirical Analysis on the Relationship between Ownership Structure and Corporate Performance of Liquor Listed Companies
}

\author{
Yang Gao \\ School of Management, Wuhan University of Technology, Wuhan, P.R.China, 430070
}

379957674@qq.com

Keywords: Listed companies of the liquor industry; Ownership structure; Corporate performance

\begin{abstract}
As the basis of the corporate governance structure, the equity structure has always been a hot topic in the field of corporate governance research. As a representative industry in consumer goods industry, the liquor industry plays an important role in promoting China's economic development. This paper summarizes a series of relevant research literature at home and abroad, and researches how the ownership concentration and equity balance degree impact on the corporate performance by the method of normative analysis. Then this paper selects the data of annual reports published by eighteen listed companies of the liquor industry from 2015 as the research sample, and builds an evaluation system of corporate performance which covers twelve financial indicators in terms of the debt paying ability, operation ability, profit ability and development ability by using the method of factor analysis. The comprehensive score of performance calculated is used as the dependent variable, ownership concentration and equity balance degree as the independent variables with the company size and financial leverage as the control variables. Then by building multivariate regression models and under the help of SPSS 19.0 statistical analysis software, this paper researches the relationship between ownership concentration, equity balance degree and corporate performance using the method of empirical analysis.
\end{abstract}

\section{Introduction}

Domestic and foreign scholars have made a lot of research on the relationship between ownership structure and corporate performance, and most of them believe that the ownership structure has a positive effect on business performance. But, according to the existing empirical research conclusions, we are unable to draw a consistent conclusion about how the ownership structure affects the corporate performance.

Berle and Means (1932)[1] are the first scholar to research the relationship, they find there is a positive relationship between ownership structure and corporate performance. Thomsen and Pedersen (2000)[2] choose 12 European countries and 435 big companies as research samples, and finally find there is a significant positive relationship between ownership structure and corporate performance (ROA) .Wukang Su (2003)[3] choose all the companies which are listed in Shenzhen and Shanghai Stock Exchange before 2001 as the research samples, get the same conclusion through regression analysis.

La Porta and Shleifer (1999)[4] find that there are often inconsistent interests between controlling shareholders and small shareholders, which causes the interests of the conflict occurred.At this point, the operating performance of the equity dispersed company is better than that of the company under the mode of equity concentration. In other word, there is a negative relationship between ownership structure and corporate performance. Yajing Li,Hongquan Zhu,Dengshi Huang,Yingfeng Zhou (2006)[5] and Jie Hu, Ying Hu(2006)[6] get the same conclusion,but the relationship is not significant.

Cho Myeong-Hyeon (1998)[7] do research on the 1993-1995 years' relevant data of 500 manufacturing companies , conclude that: the relationship between the proportion of internal shareholders and the value of the company is the $\mathrm{N}$ type curve. While Deping Chen and Yongsheng Chen(2011)[8] find the curve is U type.

Wuxiang Zhu and Yong Song (2001)[9] select 20 listed companies of China's home appliance 
industry as the research object, conclude that: there is no significant relationship between ownership structure and corporate performance. Demsetz (1983)[10] get the same conclusion.

Throughout the domestic and foreign scholars' research results, we find that the relationship between ownership structure and corporate performance has not formed a consistent conclusion. This paper selects the liquor industry in our country as the research samples; provide a further empirical evidence for relationship between ownership structure and corporate performance.

\section{Empirical Analysis}

Sample Selection. This paper selects the listed companies in Shanghai and Shenzhen Stock Exchange in 2015 as the research sample. Finally we get 18 listed companies in total, which include Yilite, Gold Seed Wine, Kweichow Moutai, Laobaigan Wine, Tuopai Shede, Shuijingfang, Shanxi Fen, Luzhou Laojiao, Gujing Distillery, Jiugui Wine,Wuliangye, Tibet Fazhan, Lanzhou Huanghe, Mogao Gufen, Changyu 2A, Guyue Longshan, Jinfeng Wine and Hainan Yedao .Data is provided by CSMAR.

Variables Selection. Variables in this study include: company performance variables, ownership structure variables and control variables,

Company performance variables: We establish a comprehensive index system to measure the performance of Listed Companies in the liquor industry, which include debt paying ability(asset liability ratio $X 1$, current ratio $X 2$, cash ratio $X 3$ ), operational capability(turnover rate of current assets X4, total assets turnover X5), profitability (return on net assets X6, total net profit margin X7, net profit margin $\mathrm{X} 8$, cost and profit margin X9),growth capacity (main business income growth rate $\mathrm{X} 10$, net profit growth rate, capital accumulation rate $\mathrm{X} 11$ ). We use $\mathrm{F}$ to stand for company performance.

Ownership structure variables: CR1 --shareholding proportion of the controlling shareholder,CR5 -- the proportion of the top five shareholders, CR10 -- the proportion of the top ten shareholders and H5 --Herfindahl Index.

Control variables: LNSIZE --company size, DAR --financial leverage. DAR is demonstrated by asset liability ratio.

Research Methodology. Statistical description, factor analysis and regression analysis are used in this paper to research the relationship between corporate performance and ownership structure. First, we use descriptive statistics to observe the ownership structure of liquor listed companies in our sample; then we use factor analysis to establish the corporate performance evaluation system; finally, we use regression analysis to get the relationship between corporate performance and ownership structure. Data processing process is completed by SPSS 19.0.

Hypothesis and Model. $H$ : There is a weak positive correlation between ownership concentration and corporate performance.

$$
F=\alpha+\beta_{i} X_{i}+\gamma_{1 i} L N S I Z E+\gamma_{2 i} D A R+\varepsilon_{i}
$$

$X_{i}$--Relevant indicator variable, $\alpha$--constant, $\beta \backslash \gamma$-- regression coefficient, $\varepsilon_{i}$--Residual.

\section{Results}

Statistical Description. Table 1 is the result of descriptive statistics, in which we can acquaintance the companies' ownership structure.

Table 1 Ownership concentration of the sample in 2015

\begin{tabular}{lllll}
\hline & CR1 $>20 \%$ & CR5 $>50 \%$ & CR10>50\% & H5<25\% \\
\hline Number & 15 & 7 & 8 & 12 \\
Proportion & $83.33 \%$ & $38.89 \%$ & $44.44 \%$ & $66.67 \%$ \\
\hline
\end{tabular}


Overall, the company equity of liquor industry is highly concentrated in the top five shareholders, while focusing on the largest shareholder.

Factor Analysis. Table 2 is the result of factor analysis.

Table 2 Component Score Coefficient Matrix

\begin{tabular}{|c|c|c|c|}
\hline & \multicolumn{3}{|c|}{ Component } \\
\hline & 1 & 2 & 3 \\
\hline $\mathrm{X} 1$ & .086 & -.235 & -.053 \\
\hline $\mathrm{X} 2$ & .126 & -.165 & -.154 \\
\hline $\mathrm{X} 3$ & -.050 & .251 & .064 \\
\hline $\mathrm{X} 4$ & .150 & -.063 & -.132 \\
\hline $\mathrm{X} 5$ & -.049 & -.067 & -.445 \\
\hline X6 & -.070 & -.070 & 674 \\
\hline X7 & . 088 & .252 & -.150 \\
\hline $\mathrm{X} 8$ & . 103 & 243 & -.170 \\
\hline X9 & .207 & .020 & .029 \\
\hline X10 & .202 & .052 & .043 \\
\hline X11 & .187 & .007 & .134 \\
\hline $\mathrm{X} 12$ & .175 & -.033 & -.079 \\
\hline
\end{tabular}

Principal component factor score model: $F=\sum_{i=1}^{12} a_{i} X_{i}$

According to the score of each financial index and Principal component factor score model, we can get the calculation formula of each principal component.

$\mathrm{F} 1=0.086 \mathrm{X} 1+0.126 \mathrm{X} 2-0.050 \mathrm{X} 3+0.150 \mathrm{X} 4-0.049 \times 5-0.070 \times 6+0.088 \times 7+0.103 \times 8+0.207 \mathrm{X} 9+0.2$ $02 \times 10+0.187 \times 11+0.175 \times 12$

$\mathrm{F} 2=-0.235 \mathrm{X} 1-0.165 \times 2+0.251 \times 3-0.063 \times 4-0.067 \times 5-0.070 \times 6+0.252 \times 7+0.243 \times 8+0.020 \times 9+0.0$ $52 \mathrm{X} 10+0.007 \mathrm{X} 11-0.033 \mathrm{X} 12$

$\mathrm{F} 3=-0.053 \mathrm{X} 1-0.154 \mathrm{X} 2+0.064 \mathrm{X} 3-0.132 \mathrm{X} 4-0.445 \times 5+0.674 \mathrm{X} 6-0.150 \times 7-0.170 \times 8+0.029 \mathrm{X} 9+0.04$ $3 \mathrm{X} 10+0.134 \mathrm{X} 11-0.079 \mathrm{X} 12$

Finally, we get the formula of the corporate performance:

$$
\mathrm{F}=(0.38664 \mathrm{~F} 1+0.29271 \mathrm{~F} 2+0.11132 \mathrm{~F} 3) / 0.79067
$$

Regression Analysis. We analyze the linear regression of $\mathrm{CR} 1$ and $\mathrm{F}$ in accordance with the previous model, and get the regression coefficient of 0.564 , but the result is not significant. Further we do regression analysis to research the relationship between $\mathrm{F}$ and $C R 1^{2}$,we find there is not a secondary nonlinear relationship between them. In summary, we can say there is a weak positive correlation between ownership concentration and corporate performance.

At the same time, we do linear regression analysis to CR5, CR10 and H5, regression coefficients are $0.450,0.855$ and 0.091 , but the results are not significant, too. These results also prove our hypothesis.

\section{Conclusion}

According to the factor analysis, descriptive statistics analysis, correlation analysis and regression analysis of the ownership concentration and corporate performance of 18 listed companies in 2014, the author get the following conclusion in the end:

There is a weak positive correlation between ownership concentration and corporate performance.. There may be the following reasons:

First of all, instead of taking factors such as nature of equity, stock liquidity into account, this 
paper only studies the relationship between ownership concentration and corporate performance. In terms of the measure of the ownership concentration, although selecting the multiple index, the author doesn't think more about the possible relationship between large shareholders which will affect the accuracy of the research conclusion.

Secondly, in real life, there are many factors which affect the corporate performance of liquor-making industry. This thesis only embarks from the equity structure and considers the impact on business performance. Some difficult quantifiable factors are not taken into account such as politics, economy, technology and culture and so on which will have a big effect on the business performance.

Finally, because of the imperfect of China's capital market, the book indicators chosen by some companies, and manipulation phenomenon of financial index by some managers, although this thesis uses factor analysis to measure the liquor-making industry performance of listed companies by building the corporate performance evaluation system of comprehensive score calculation, the accurate measurement of performance and conclusions will be effected. Nowadays, the China's capital market should adopt market indicators which can reflect the real performance.

Relevant suggestions. In view of this phenomenon, we put forward three suggestions. Firstly, maintain moderate ownership concentration: Then, reduce the gap of shareholding between the big shareholders and establish an effective ownership structure; finally, cultivate professional manager market.

\section{References}

[1] Berle, A.A. \&G.C. Means. The Modern Corporate and Private Property [M]. New Work: MacMillan., 1932.

[2] Thomsen, S. \&T.Pedersen.Ownership Structure and Economic Performance in the Largest Companies [J].Strategic Management Journal, 2000, (21):689-606.

[3] Wukang Su.An empirical study on the ownership concentration and corporate performance of Chinese Listed Companies [J].Reform of Economic System2003, (3):111-114. (In Chinese)

[4] La Porta,R.\&A.Shleifer.Corporate Ownership around the World[J].Journal of Finance,1999, (54):471-517.

[5] Yajing Li,Hongquan Zhu,Dengshi Huang and Yingfeng Zhou.Ownership Structure and Corporate Value Creation[J].Journal of Management Science,2006,(10):65-74.(In Chinese)

[6] Jie Hu and Ying Hu.An empirical analysis on the relationship between ownership structure and corporate performance of listed companies [J].Management World, 2006,(3):142-143.(In Chinese)

[7] Myeong-Hyeon Cho. Ownership Structure Investment,and the Corporate Value:An Empirical Analysis[J],1998,(47):102-120.

[8] Deping Chen and Yongsheng Chen.A study on the relationship between ownership concentration, ownership restriction and firm performance:an empirical Study of the 2007-2009 Small and medium sized enterprises[J].Accounting Research,2011,(1):34-83.(In Chinese)

[9] Wuxiang Zhu and Yong Song.Equity structure and firm value in home appliance industry listed companies' empirical analysis [J].Economic Research, 2001, (12):66-72. (In Chinese)

[10] Demsetz, H. The Structure of Ownership and the Theory of the Firm [J]. Journal of Law and Economics1983, (26):375-390. 